\title{
The effects of carbon-in-ash on mercury capture from
}

\section{flue gas}

\author{
Kyung Man Kim \\ University of California, Irvine \\ E-mail: kepmankim@gmail.com
}

Feng Jiang

E-mail: fengjeffjiang@gmail.com

John Garman

E-mail: jgarman@earthlink.net

Derek Dunn-Rankin

E-mail: ddunnran@uci.edu

Received: June 16, 2015 Accepted: June 29, 2015

doi:10.5296/emsd.v4i2.7820 URL: http://dx.doi.org/10.5296/emsd.v4i2.7820

\begin{abstract}
Mercury, although only a trace element in coal, is an important pollutant because coal burning is increasing around the world for manufacturing and energy production. In addition, coal-fired plants are the largest anthropogenic source of mercury emission to the environment. Mercury capture mostly occurs under heterogeneous conditions between sorbent particles and gaseous mercury, and this study is mainly devoted to understanding the role of carbon-in-ash on mercury capture from flue gas. Coal flyash samples are characterized by loss-on-ignition (LOI) carbon content, surface area (BET) tests, and scanning electron microscopy (SEM) morphology. Flyash sorbents are injected using an in-flight configuration and then mercury concentration is measured by $\mathrm{Hg}$ continuous emission monitoring system (CEMS). The unburned carbon in ash is found to be one main factor for capturing mercury. In addition, mercury capture increases when flyash samples have more surface area. Carbon in ash is also positively correlated with surface area within coal rank. This suggests that unburned carbon plays a formative or structural role in surface area increase on flyash. However, mercury uptake is shown to be relatively low when using flyash from high rank coal such as anthracite because of the small surface area coming from its non-porous structure. Therefore, when flyash is used as a sorbent for mercury capture, quantitative surface area should be compared and coal rank also should be considered. Carbon content in ash as mercury capture sorbents is
\end{abstract}


a good indicator for mercury capture, but its surface area should also be considered for predicting mercury uptake.

Keywords: Mercury, Capture, Surface Area, Carbon Content, Flyash

\section{Introduction}

The use of coal has been increasing steadily, and the large demand for power in developing nations suggests that coal will continue to be a major energy source. The U.S. Energy Information Administration (EIA) predicts that the contribution of coal to the electric power sector in 2035 will reach up to 43 percent even if its portion for electricity generation declines because of environmental issues (Conti, 2010). Even though mercury is a fairly rare element in coal, it has been focused on over the last three decades because of the damaging impact of continuous anthropogenic emission levels.

The current state-of-the-art in mercury emission control from coal combustion flue gas involves direct contacting methods between activated carbon sorbents and mercury vapor. However, the corresponding sorbent cost is very high. For example, for a $250 \mathrm{MW}$ unit emitting $65 \mathrm{~kg}$ of $\mathrm{Hg}$ per year, it is estimated that it would cost between $\$ 1$ million and $\$ 3$ million to remove just 50\% of the mercury present (Romero, 2005). Accordingly, many utilities are eagerly looking for more effective and less expensive technologies to control mercury emission. To help in this search, it is important to understand the detailed mechanisms involved so that the effectiveness of sorbents can be improved and so that cost-effective alternative sorbents can be identified for mercury capture in the power industry.

The objective of the research described in this paper is to investigate mercury capture effectiveness in the post-combustion flue gas through scrutinizing detailed sorbent performance. In this regard, different dedicated sorbents are investigated with special considerations of their relative adsorption and desorption mechanisms. Overall, the enhanced understanding of the physical and chemical effects of these sorbents can help improve the prediction of mercury uptake in the post combustion region of coal burning utility boilers.

\section{Research Approach and Method}

This research focuses on heterogeneous interactions between coal flyash used as a sorbent and gaseous mercury vapor. Coal flyash is a complicated sorbent to consider because each flyash can have different characteristics depending both on the original coal feedstock and on the combustion process the coal underwent (Serre, 2000). This research concentrates, therefore, on the key features of flyash that have been identified as important factors in mercury capture. They are the residual carbon content (also known as carbon-in-ash, as characterized by loss-on-ignition or LOI), the specific surface area, and the pore structure. The chemical makeup of the flyash is not considered in detail, but the evidence suggests that these factors are secondary to those mentioned above.

\subsection{Flyash Samples and Characterization Methodology}

In order to evaluate the physical adsorption mechanism of mercury onto flyash in the post combustion region, five flyash samples of varying source coal ranks were used for injection as sorbent through the mercury capture based on coal ranks. The flyash samples tested in this study were all collected from coal-fired utility boilers and were donated by a power generation company and Fossil Energy Research Corporation (FERCo). Among the samples, flyash III comes from a fluidized bed boiler and the other flyash samples are from pulverized coal combustion boilers. The general properties such as coal rank, source coal, LOI on the flyash samples is shown in Table 1. 


\section{Macrothink}

The carbon content in flyash samples is examined by a LOI test. LOI is a typical indirect measurement used as an index for the unburned carbon content in flyash. Even when other semi-volatile organic minerals are included, LOI is known to be a good evaluation of unburned carbon fraction. A FERCo Hot Foil LOI (HF400, Fossil Energy Research Corporation, Lake Forest, California) instrument and an analytical scale with a precision of $0.01 \mathrm{mg}$ are used for LOI testing. For surface area characterization of flyash samples, a nitrogen based Autosorb-1 surface area and pore size analyzer is utilized. The structure and phase of the samples are investigated using a Scanning Electron Microscopy (SEM). Lastly, approximate size distributions for the flyash samples are tested by sieve separation using ASTM E-11 specifications. The sorting by size of particles simulates natural ash particles in the post combustion region, including agglomeration. Because agglomerates naturally form, air-borne ash particle size distribution can be different from measurements where the samples are dispersed in a liquid solution ultrasonically.

Table 1. General properties of flyash samples

\begin{tabular}{|c|c|c|c|}
\hline Flyash & Color, shape & Source coal & LOI (\%) \\
\hline Flyash I & Light brown, powder & PRB sub-bituminous & 0.42 \\
\hline Flyash II & Dark brown, powder & Alabama bituminous & 2.61 \\
\hline Flyash III & Dark gray, powder & Utah bituminous & 16.41 \\
\hline Flyash IV & Dark gray, powder & Anthracite & 9.80 \\
\hline Flyash V & Dark gray, powder & Bituminous & 11.66 \\
\hline
\end{tabular}

\subsection{Experimental Apparatus and Method}

In order to investigate mercury reduction depending on dedicated sorbents in the post-combustion region of coal-burning boilers, a pilot-scale experimental apparatus is built, with ductwork and sampling systems coupled with a mercury injection system to parallel the function of ductwork in power plant conditions. A schematic of the experimental apparatus is shown in Figure 1.

The experiment is performed in homogeneous conditions in order to simulate and evaluate mercury removal directly from flue gas. It also enables an assessment of the effectiveness of different sorbents, including activated carbon and native residual ash for mercury capture in heterogeneous situations. The experimental setup can be divided into 4 sections, as shown in Figure 1: (1) continuous emission monitoring system (CEMS), (2) main duct system in the post combustion region, (3) sorbent injection system and air delivering system, and (4) flue gas delivery system. 


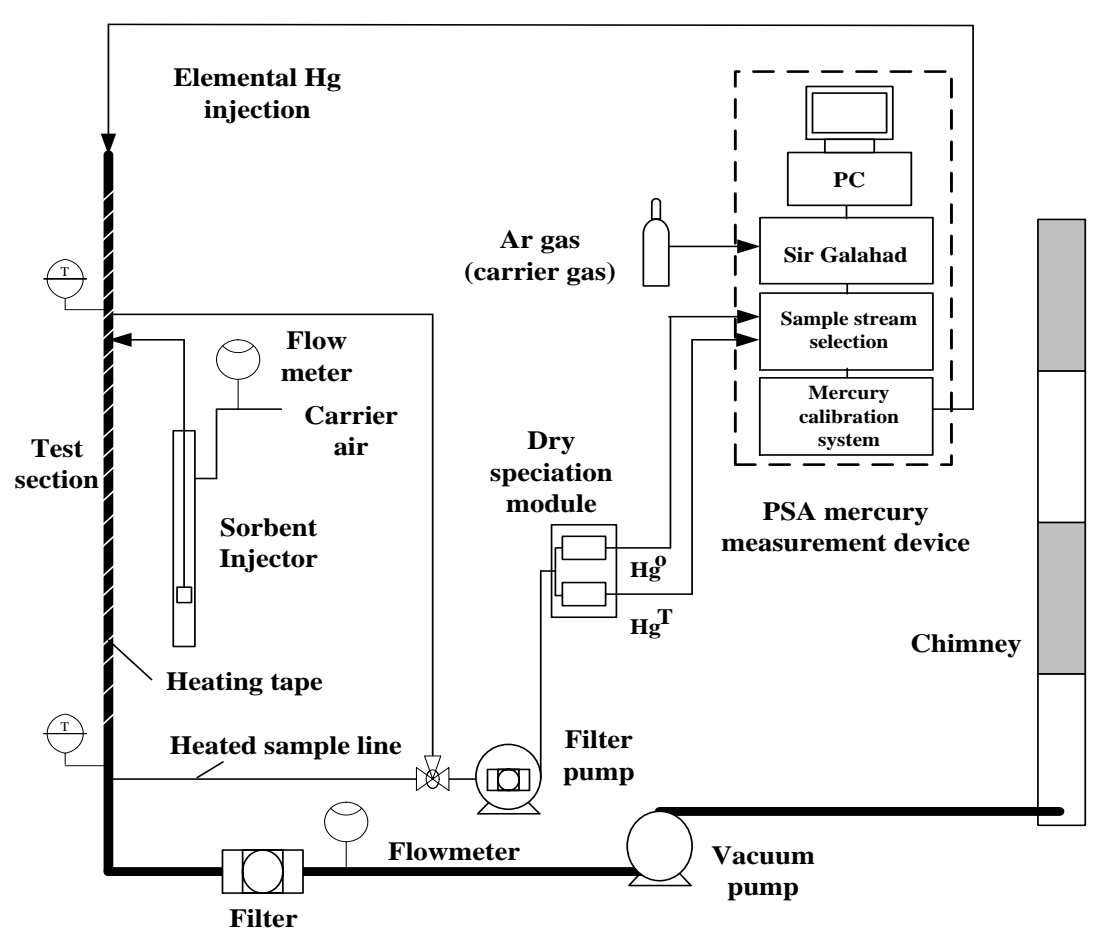

Figure 1. Experimental apparatus for mercury capture by flyash samples

The elemental mercury injection system from the PSA mercury calibration module is shown in Figure 2. Saturated mercury flow and air flow for dilution are regulated by Mass Flow Controller (MFC). The mercury bearing flue gas is introduced into the test section. Flyash samples are injected using the particle feeder. Mercury concentration is measured by the PSA 10.525 EX Sir Galahad II before and after flyash injection to evaluate mercury removal efficiency in the test section. The test section is treated with special coating to prevent mercury loss on the wall and is heated to minimize mercury vapor condensation.

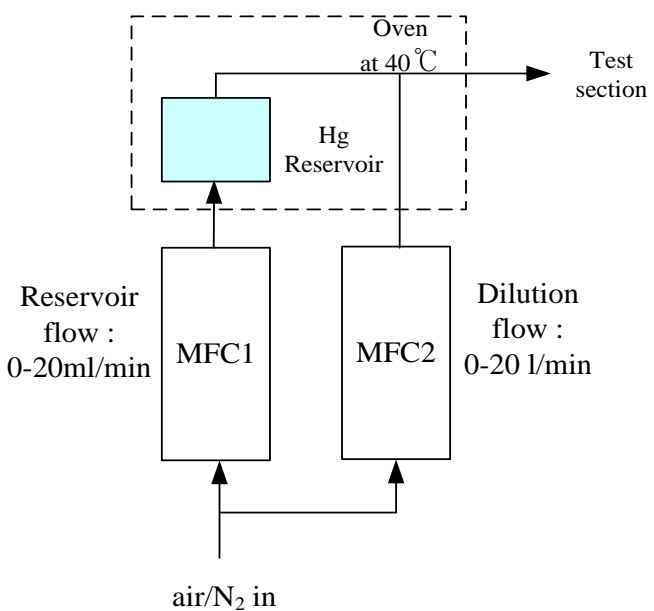

Figure 2. Cavkit 10.536 Mercury Calibration Module

Figure 3 shows the custom designed and built aspirated particle feeder for fine sorbent particles used in the current experiments. Carrier air flows into the feeder cylinder and escapes via the center tube supporting a piston. Sorbent particles are carried upwards with the 


\section{Macrothink}

Environmental Management and Sustainable Development

ISSN 2164-7682

carrier air as the piston approaches the surface of the sorbent. The sorbent particle feed rate is controlled by manipulating the relative velocity between the piston and the reservoir cylinder using a slide controlled by a stepper motor. The particle feeder provides in-flight interaction between flyash and mercury vapor because mercury vapor is generally captured in air-borne conditions in power plants rather than through a fixed bed cake (Scala, 2008). The test section plumbing is designed vertically to minimize wall deposits. The mean residence time of a particle in the test section is approximately $2 \mathrm{sec}$, and the temperature is kept at $120^{\circ} \mathrm{C}$.

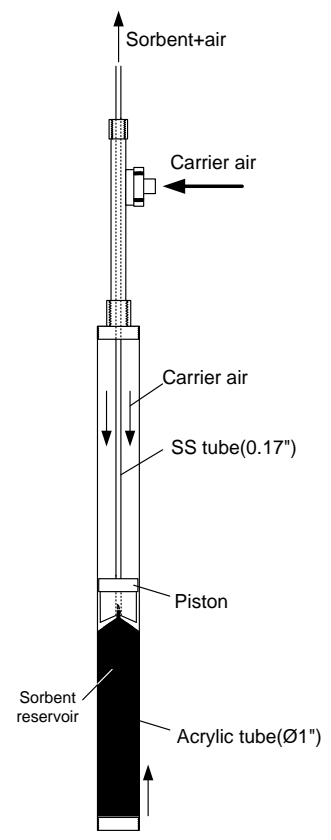

Figure 3. Aspirated particle feeder

\section{Results and Discussion}

\subsection{Flyash Sample Characterization by SEM and Standard Sieves}

The SEM image of flyash I, a PRB subbituminous, is shown in Figure 4. The flyash components have spherical particle shapes ranging from 2 to $10 \mu \mathrm{m}$ in size. The actual size after combustion appears far larger than that in the SEM image because flyash A particles agglomerate during the combustion and the post-combustion period. According to the tests of particle division by standard sieves, particle sizes greater than $212 \mu \mathrm{m}$ account for the majority of the size distribution, as seen in Figure 5. The reason that the larger particle sizes are important is that agglomeration results in a reduction of surface area, which affects the mercury uptake performance of flyash as a mercury sorbent. 


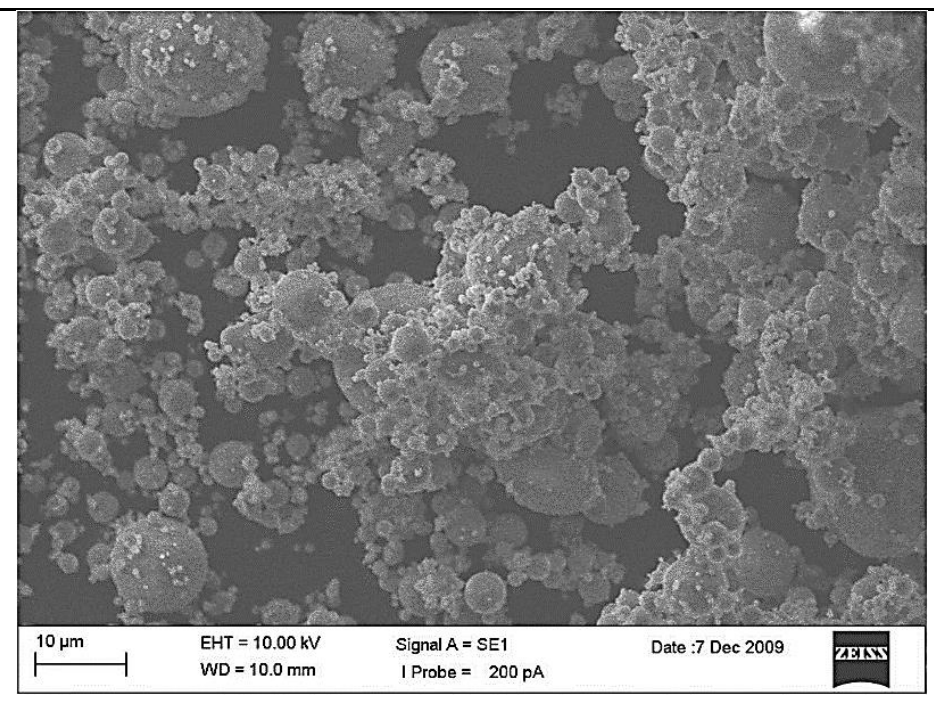

Figure 4. Flyash I SEM image

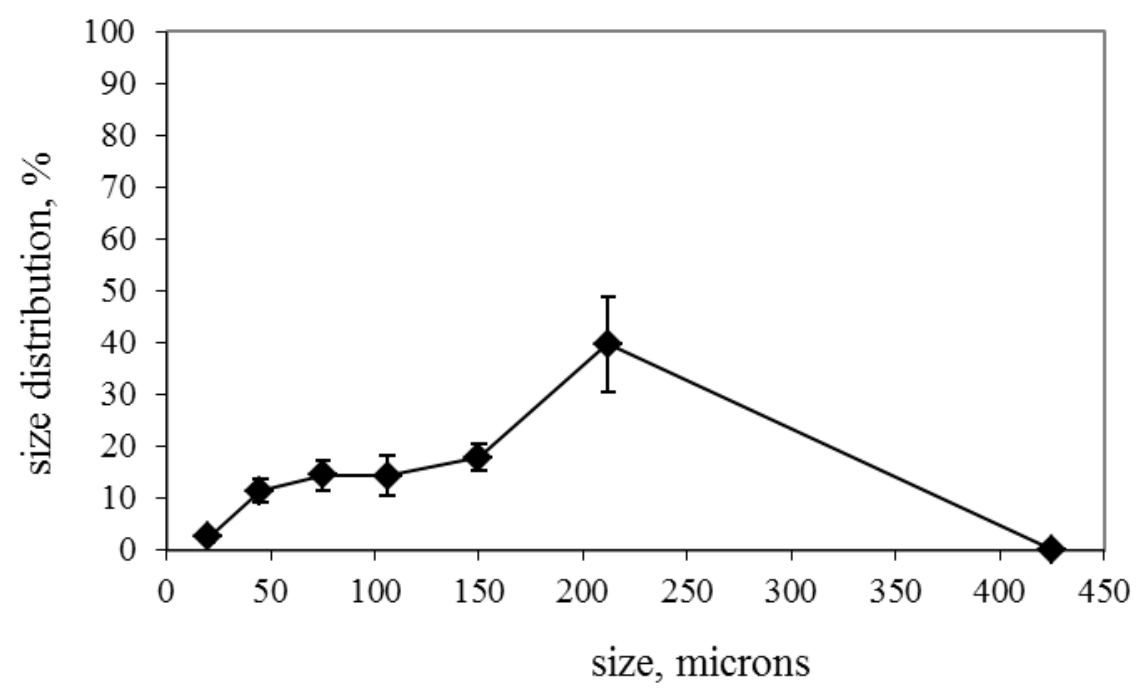

Figure 5. Flyash I (sub-bituminous) size distribution by standard sieves

Dark brown flyash II is bituminous coal flyash (see Figure 6). It has 10-20 $\mu$ m mean diameter and does not show the severe agglomeration of flyash I. This flyash sample shows a coarse particle shape compared to flyash I. In addition, it has a regular particle distribution with very few spherical fine particles, according to SEM image analysis. The sieve-based particle size distribution for flyash II is shown in Figure 7. The largest fraction of the flyash sample is below $50 \mu \mathrm{m}$ by sieves because there is little agglomeration. 


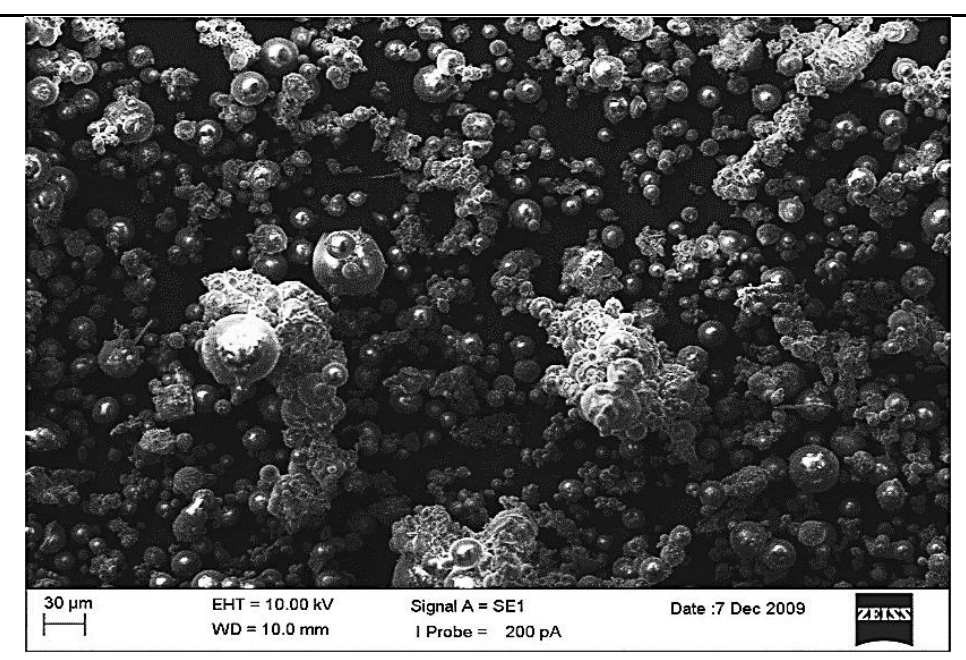

Figure 6. Flyash II SEM image

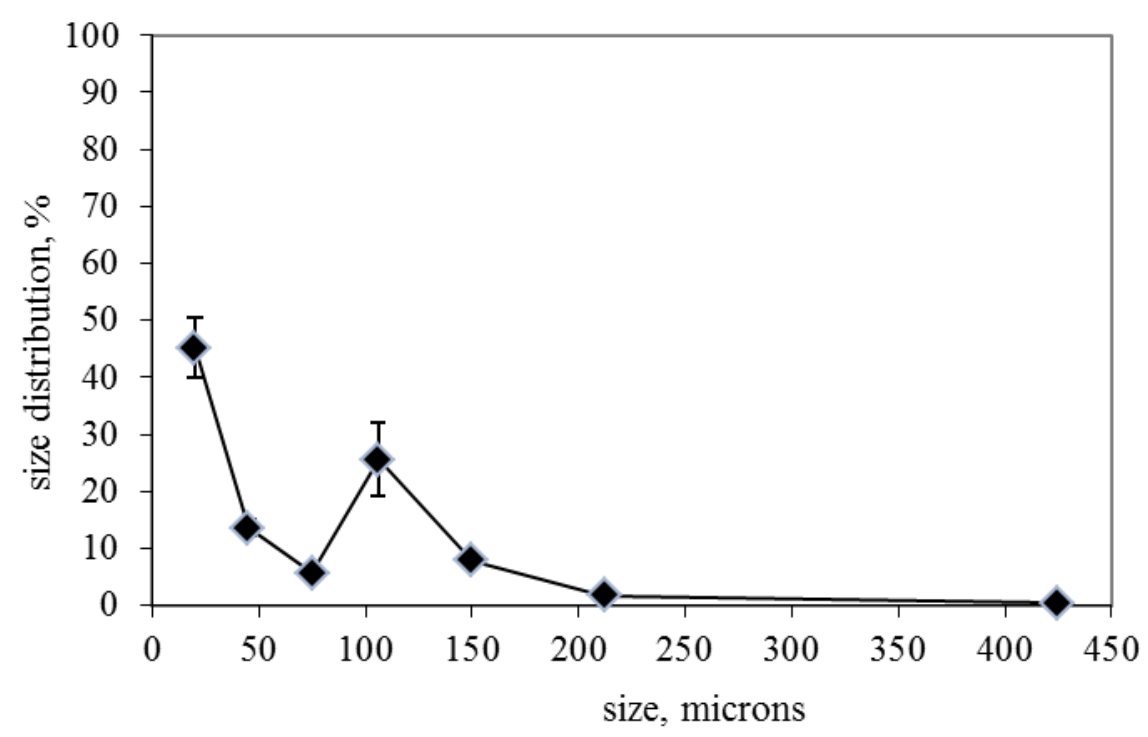

Figure 7. Flyash II (bituminous) size distribution by standard sieves

Flyash III is a Utah bituminous and shows the highest LOI content of the investigated flyash samples with 16.4 percent. The boiler producing this flyash sample uses fluidized bed combustion (FBC) with medium-sized coal particles. The particle shape of this flyash, identified with SEM and shown in Figure 8, turns out to be far more amorphous than the ash resulting from pulverized coal combustion (PCC) because for FBC the operation temperature is relatively low (below $1100 \mathrm{~K}$ ) and the residence time of coal particles is long (several minutes) for combustion, with coal particle sizes 1-3 mm in diameter (Bartok, 1991). FBC flyash particle sizes by standard sieves span the range of 10-150 $\mu \mathrm{m}$ as shown Figure 9. Note that agglomeration does not appear to occur based on the flyash image. 


\section{Macrothink

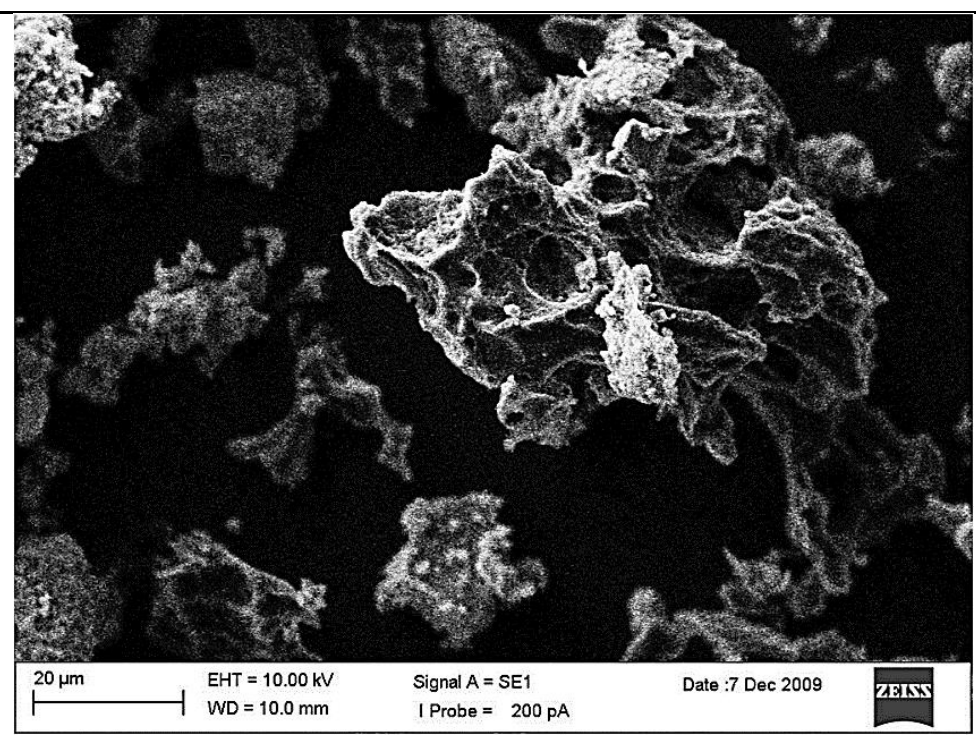

Figure 8. Flyash III SEM image

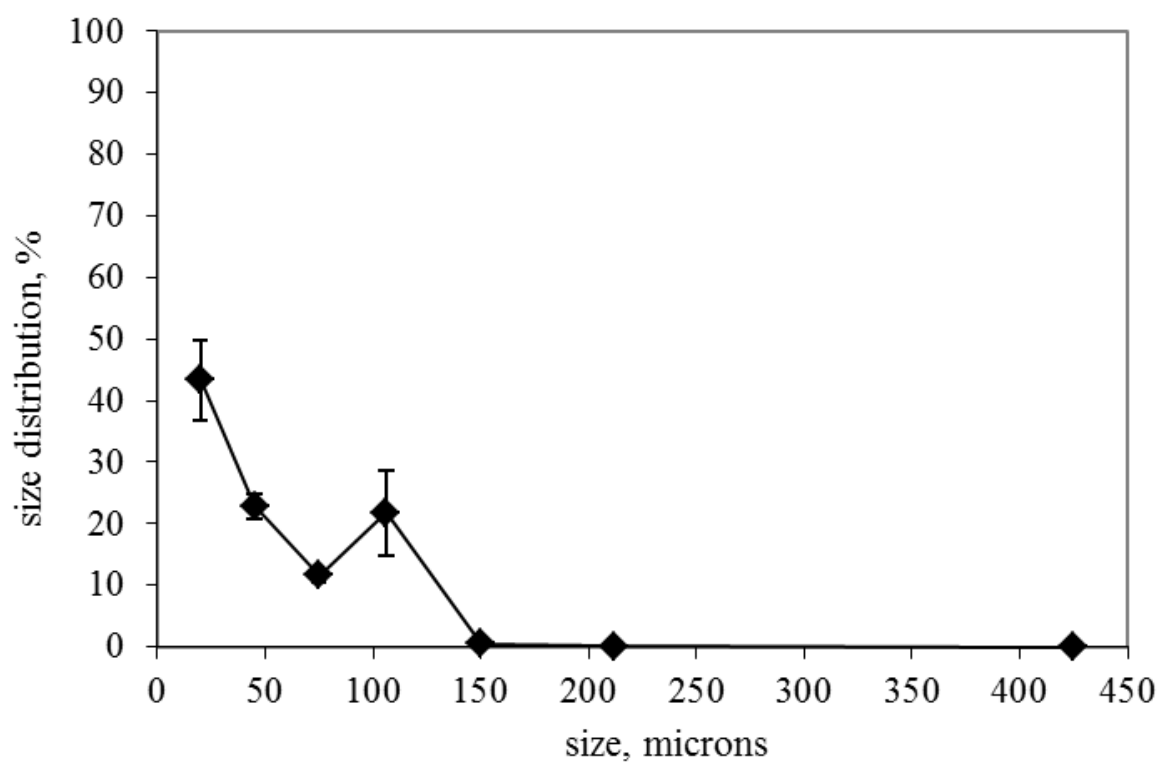

Figure 9. Flyash III (bituminous) size distribution by standard sieves

Flyash IV has 9.8 percent LOI and its source coal is anthracite. It shows a low level of agglomeration as shown in Figure 10. The unburned carbon content for Flyash V shows 11.6 percent as bituminous coal flyash. Interestingly, the larger sizes sorted by sieves show higher LOI content for both flyash samples. This fact indicates that the temperature in the boiler may not have been high enough to burn completely the source coal, or that the initial pulverization status may have created particles larger than desired. According to the SEM image, flyash V (refer to Figure 12) has similar morphology to that of flyash sample II. The characteristics of fly ash samples have been tabulated in Table 2 for comparisons. 


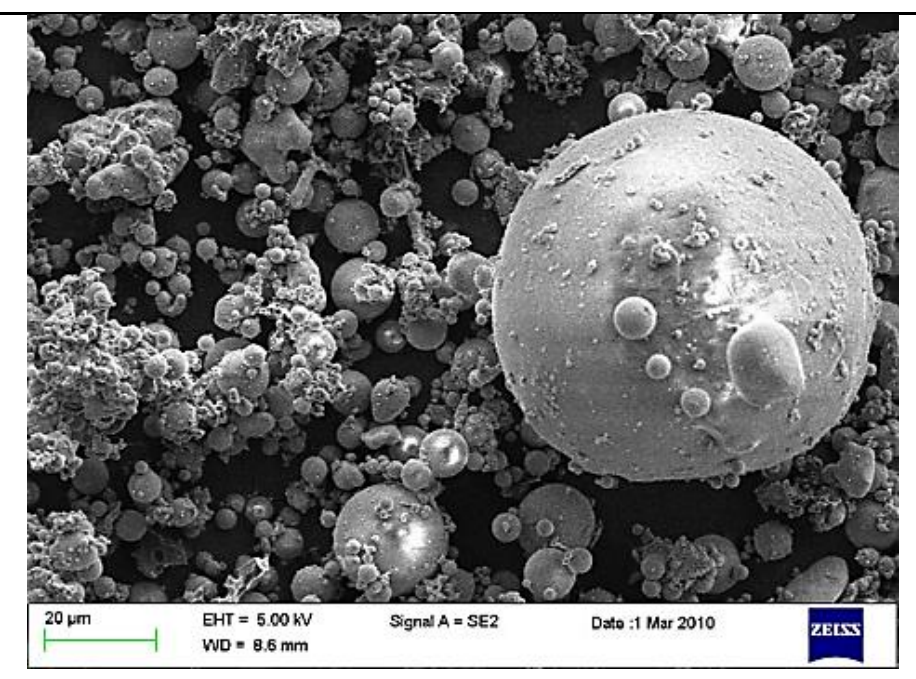

Figure 10. Flyash IV SEM image

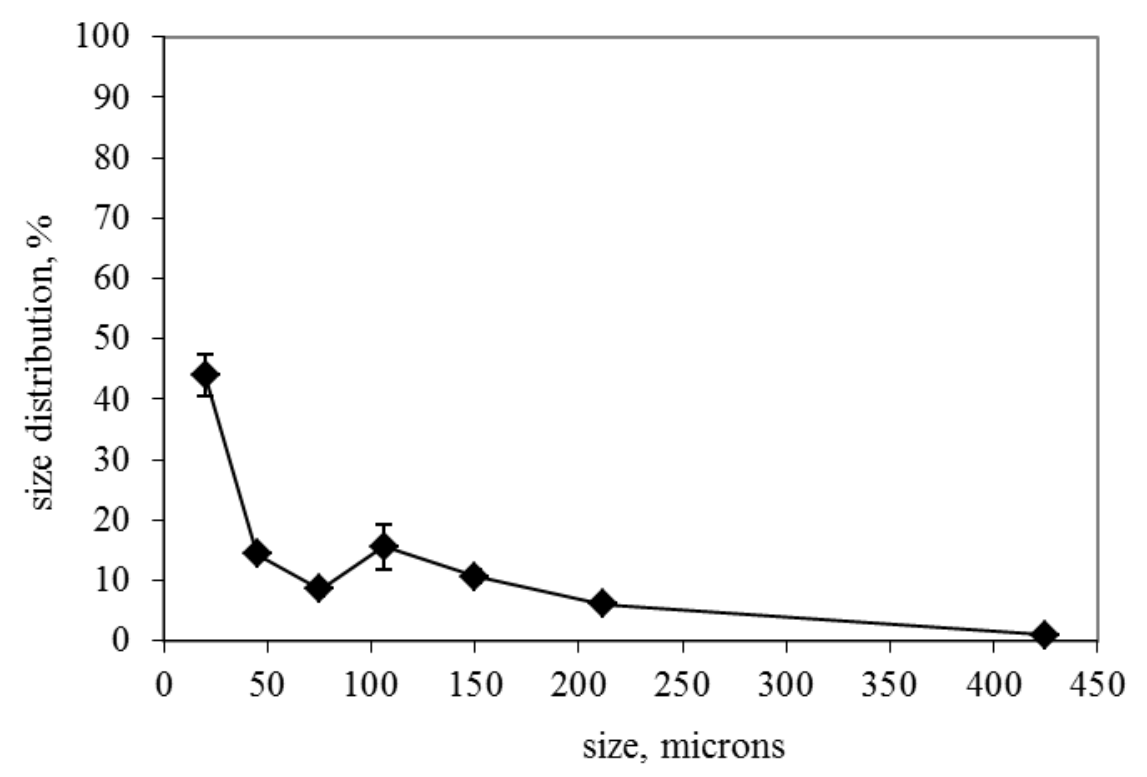

Figure 11. Flyash IV (anthracite) size distribution by standard sieves 


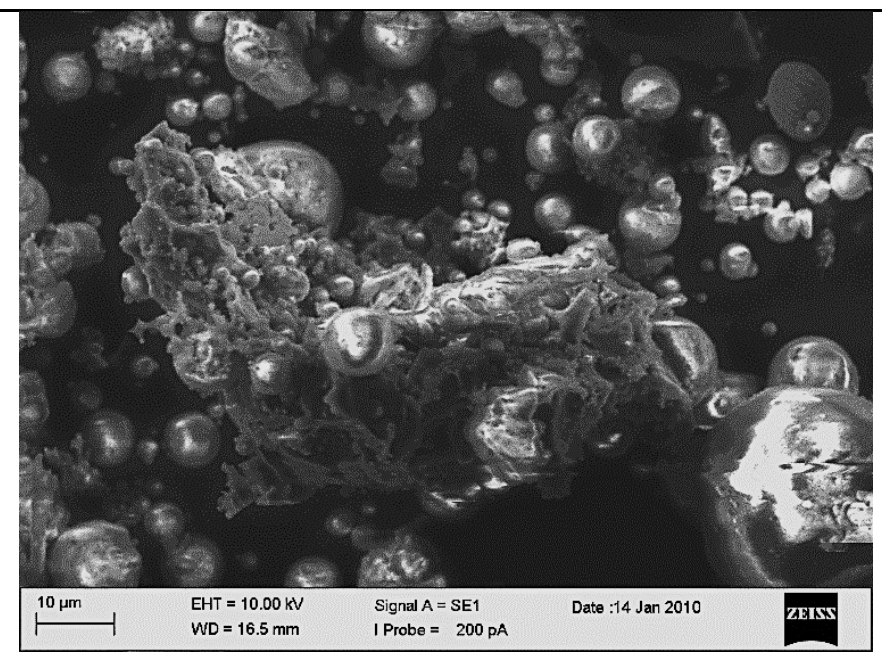

Figure 12. Flyash V SEM image

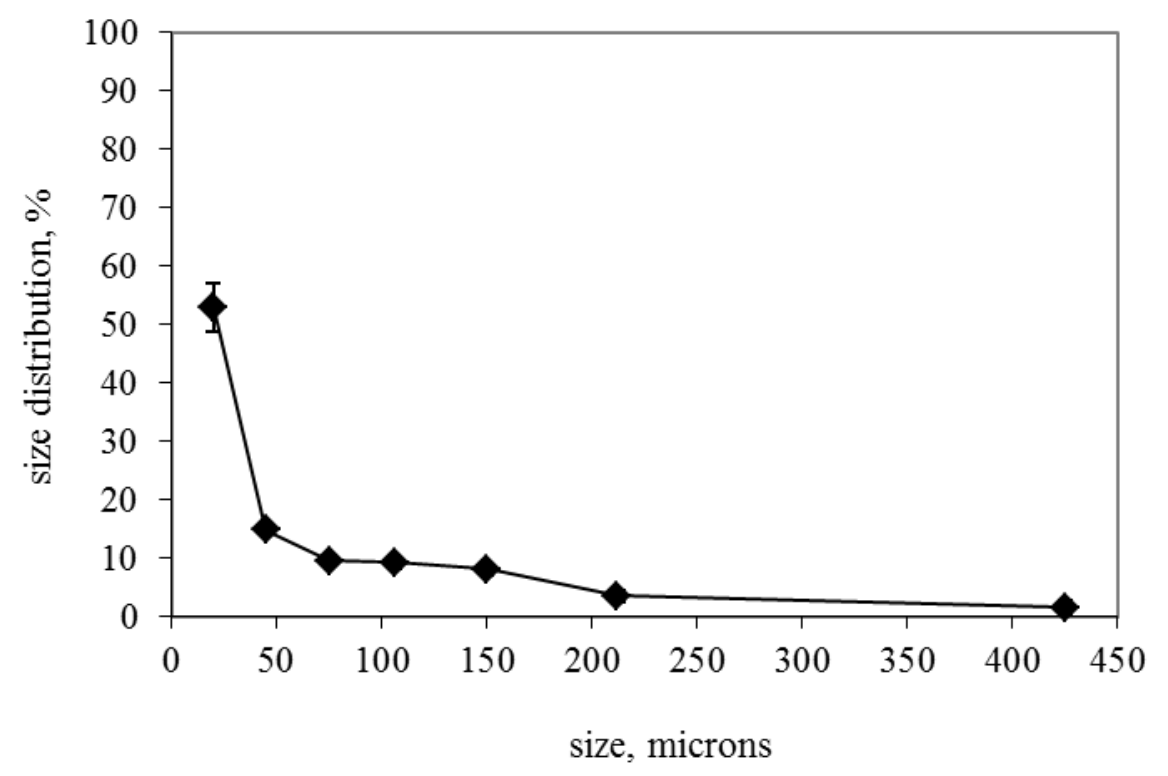

Figure 13. Flyash V (bituminous) size distribution by standard sieves 
Table 2. Characteristics of flyash samples

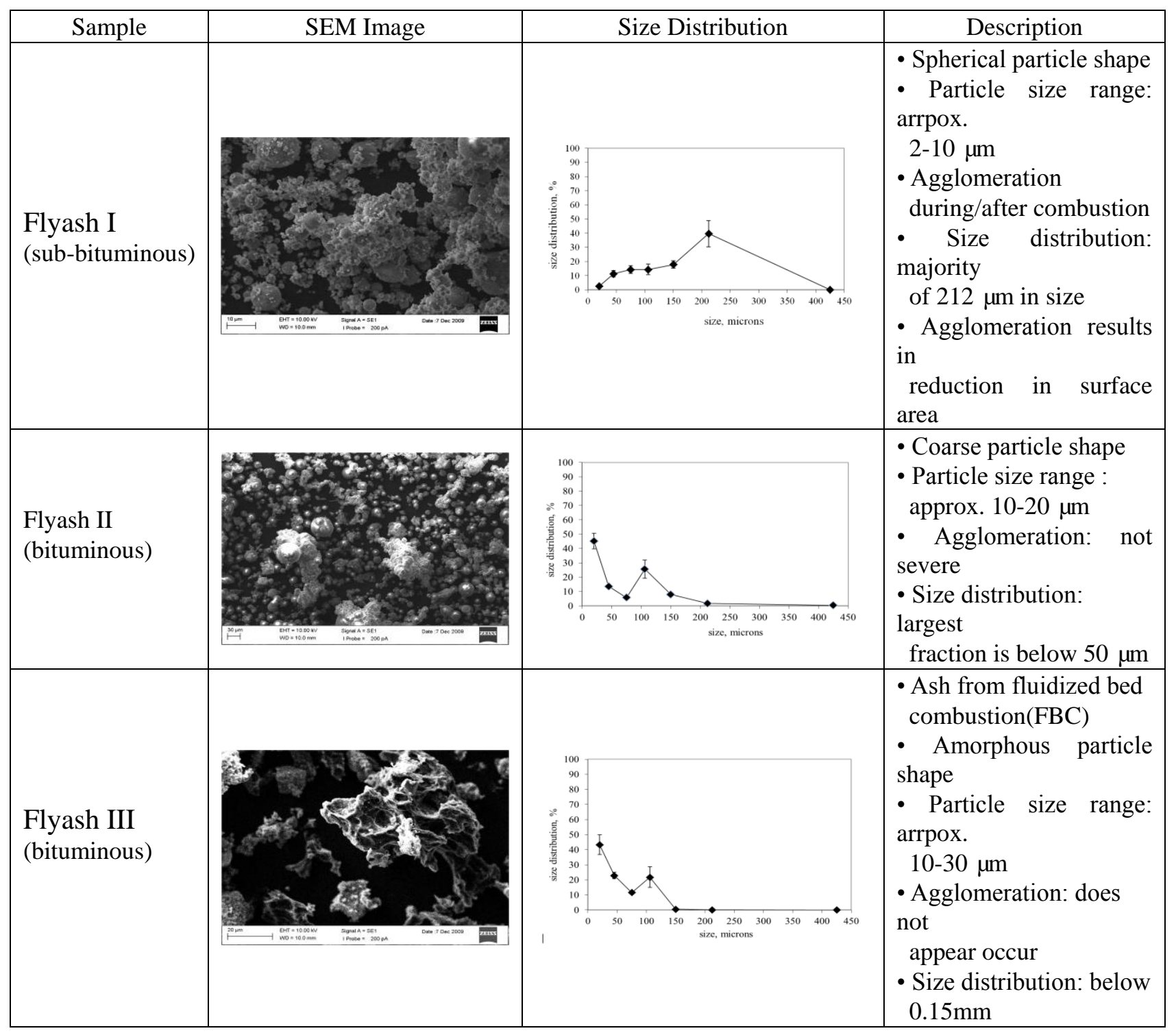




\section{Macrothink $\Lambda$ Institute}

\begin{tabular}{|c|c|c|c|c|}
\hline $\begin{array}{l}\text { Flyash IV } \\
\text { (Anthracite) }\end{array}$ & & & $\underbrace{100}_{50} \begin{array}{l}150 \\
\substack{200 \\
\text { size, nicrons }}\end{array}$ & $\begin{array}{l}\text { - Spherical particle shape } \\
\text { - Particle size range: } \\
\text { arrpox. } \\
5-40 \mu \mathrm{m} \\
\text { - Agglomeration: low } \\
\text { level } \\
\text { - Size distribution: below } \\
50 \mu \mathrm{m} \text { in size }\end{array}$ \\
\hline $\begin{array}{l}\text { Flyash V } \\
\text { (bituminous) }\end{array}$ & $D_{2}=0$ & $\begin{array}{l}60 \\
50 \\
40 \\
30 \\
20\end{array}$ & 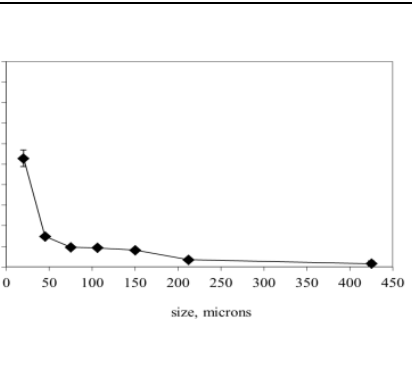 & $\begin{array}{l}\text { - Coarse particle shape } \\
\text { - Particle size range: } \\
\text { arrpox. } \\
5-15 \mu \mathrm{m} \\
\text { - Agglomeration: not } \\
\text { severe } \\
\text { - Size distribution: below } \\
212 \mu \mathrm{m} \text { in size }\end{array}$ \\
\hline
\end{tabular}

Environmental Management and Sustainable Development

ISSN 2164-7682

2015, Vol. 4, No. 2

- Spherical particle shape - Particle size range: arrpox.

- Agglomeration: low level $50 \mu \mathrm{m}$ in size

- Particle size range: arpox

- Agglomeration: not $212 \mu \mathrm{m}$ in size 


\subsection{Mercury Removal Efficiency versus Carbon Content in Flyash}

Flyash I, II, and III are examined for their performance in mercury removal. The LOI value for the flyash samples are presented in Table 1. Mercury removal efficiency of the sorbents based on LOI is shown in Figure 14. Mercury removal efficiency increases steadily against residual carbon content. Not surprisingly, because the mercury capture is not linearly proportional, these results show that capture efficiency is not simply a matter of carbon content. Surface area is another likely contributor. Providing insights into the relative roles of these two important sorbent properties for mercury capture is a major aspect of this study.

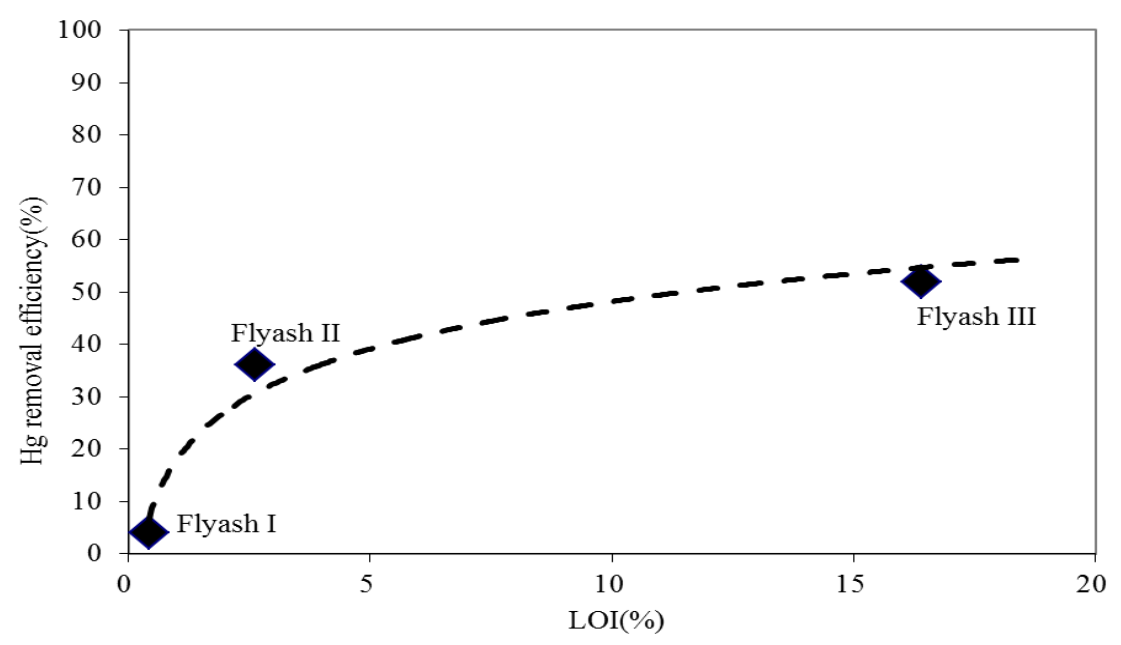

Figure 14. Mercury removal efficiency depending on LOI

The ratio of carbon content of the sorbents to mercury content in the gas phase is not linearly proportional to $\mathrm{Hg}$ removal efficiency. For example, when flyash II and flyash III are compared, the difference of $\mathrm{C}: \mathrm{Hg}$ ratio is approximately 6 times higher for flyash III (refer to Table 3). Hg capture efficiency, however, shows a gap of around 16 percent between them. The experimental results are well characterized by carbon/Hg ratio for the sorbents compared to a previous study (Serre, 2000). The relationship between increased mercury capture and higher residual carbon content can be investigated further by morphology and with the BET surface area test.

Table 3. Comparison of $\mathrm{C} / \mathrm{Hg}$ ratio based on sorbents

\begin{tabular}{|c|c|c|c|}
\hline Item $\quad$ Sample & $\begin{array}{c}\text { Flyash I } \\
\text { sub-bituminous }\end{array}$ & $\begin{array}{c}\text { Flyash II } \\
\text { bituminous }\end{array}$ & $\begin{array}{l}\text { Flyash III } \\
\text { bituminous }\end{array}$ \\
\hline LOI & 0.42 & 2.61 & 16.41 \\
\hline Sorbent injection rate $(\mathrm{g} / \mathrm{min})$ & 0.20 & 0.20 & 0.20 \\
\hline Sorbent carbon mass per volume $\left(\mathrm{g} / \mathrm{m}^{3}\right)$ & 0.04 & 0.26 & 1.64 \\
\hline $\mathrm{Hg}$ mass per volume $\left(\mathrm{g} / \mathrm{m}^{3}\right)$ & $2.5 \times 10^{-4}$ & $2.5 \times 10^{-4}$ & $2.5 \times 10^{-4}$ \\
\hline $\mathrm{C}: \mathrm{Hg}$ ratio & 1680 & 10440 & 65640 \\
\hline Hg removal efficiency & $4 \%$ & $36 \%$ & $52 \%$ \\
\hline
\end{tabular}




\section{Macrothink \\ Environmental Management and Sustainable Development \\ ISSN 2164-7682 \\ 2015, Vol. 4, No. 2}

\subsection{Mercury Removal Efficiency vs Surface Area of Flyash}

When comparing the flyash samples, $\mathrm{Hg}$ capture efficiency shows a very good linearity against surface area as shown in Figure 15. It appears that mercury capture efficiency is more closely related to the parameters of available contact area and pore volume of flyash than carbon content over the investigated range.

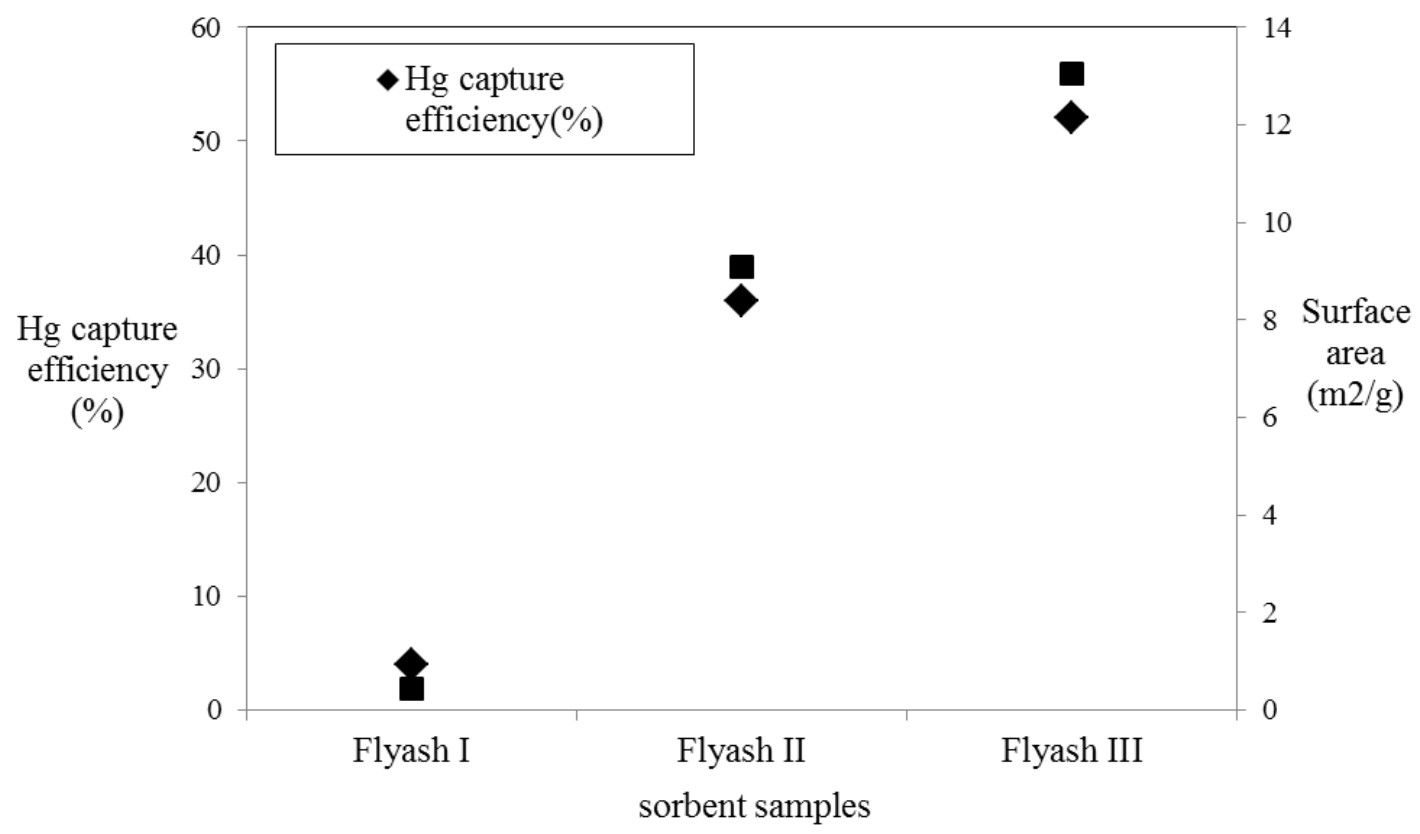

Figure 15. Mercury capture efficiency and surface area with flyash samples

The surface area attributable to residual carbon in ash is shown in Figure 16. Assuming that all combustible matter in flyash is carbon content, the surface area change "with unburned carbon content" versus "without unburned carbon content" can be checked by completely burning the flyash samples. The surface area changes from as-received flyash to after complete burning of flyash samples I, II, and III are 57 percent, 52 percent, and 68 percent respectively. Accordingly, it appears that the residual unburned carbon is responsible for more than half of the surface area in the flyash samples, even though the actual mass of carbon is vastly different in these samples. This result suggests that carbon plays a major structural role in the flyash disproportionally to its mass. The residual unburned carbon has a comparatively large surface area association because it goes through a devolatilization process during combustion in utility boilers. 


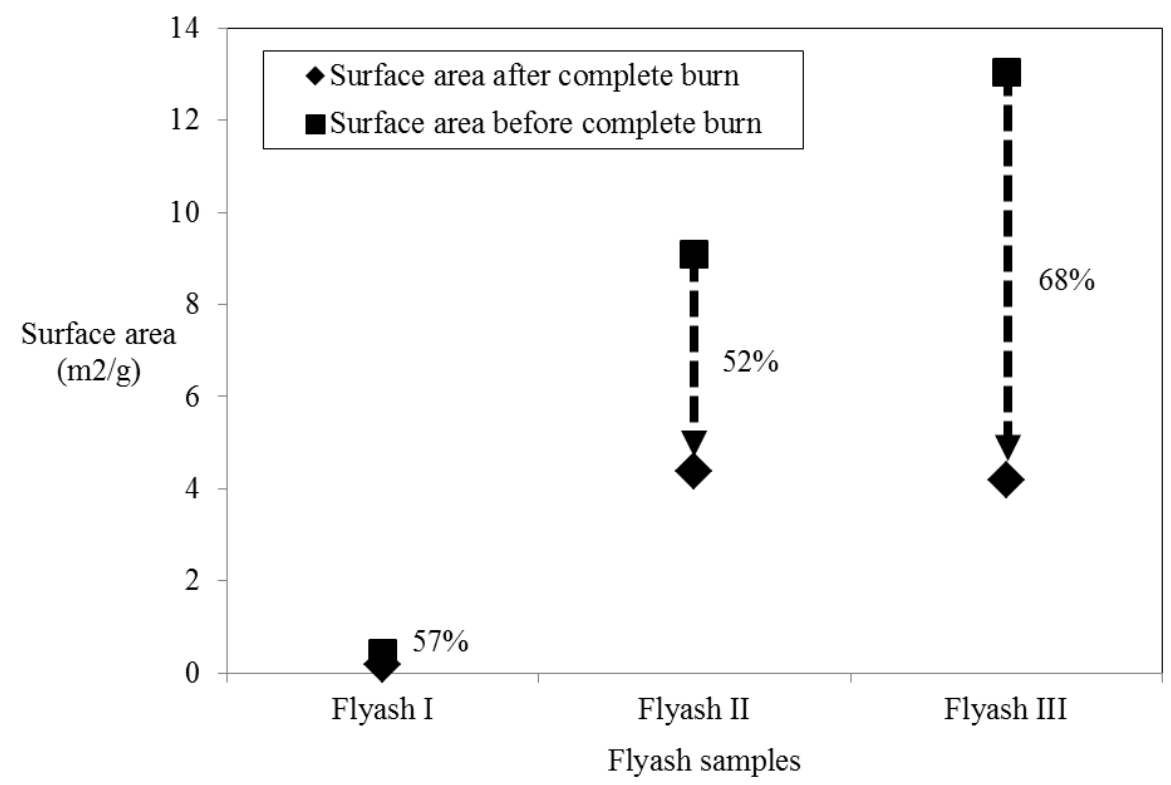

Figure 16. Surface area change rate due to complete burn

\subsection{Mercury Removal Efficiency versus Source Coal Rank}

In the previous section, it is shown that the mercury capture efficiency of flyash sorbents is closely related to the residual carbon content based on the LOI test under the condition of low rank coal such as sub-bituminous and bituminous. This finding shows that residual carbon content has a significant role in seizing mercury vapor less by its chemistry and more because of the guaranteed surface area the unburned carbon content creates in the flyash.

Since it is a physical/structural effect that seems responsible for effective mercury capture, it should be expected that not all high carbon content flyash will show a high level of performance in capturing mercury vapor. It will depend on how the carbon content correlates with surface area as well. Hence, the capacity of flyash sorbent to uptake mercury vapor will likely depend on coal rank. In order to investigate the relationship between unburned carbon content and coal rank, flyash IV and flyash V are tested. The surface area of flyash V shows $10.9 \mathrm{~m} 2 / \mathrm{g}$ and it has an 11.7 percent LOI. These values are consistent with other flyash samples such as flyash II and flyash III. However, flyash IV has a very low surface area (4.7 $\mathrm{m} 2 / \mathrm{g}$ ) even though its LOI value is 9.8 percent. This can be explained by the fact that the source coal of flyash IV has very low volatile matter content. Thus, its status after burning is a low level of surface area. This characteristic is generally associated with anthracite coal (refer to Figure 17) (Bartok, 1991). As seen earlier, unburned carbon content in flyash samples has an important role in capturing mercury, as there is a positive correlation between mercury capture capacity and unburned carbon content. However, this correlation does not apply to anthracite coal as shown in Figure 18 because insufficient surface area is generated during the devolatilization process. Accordingly, in order to make more efficient sorbent using flyash, coal having high volatile matter content should be used so that a high surface area porous structure results. 


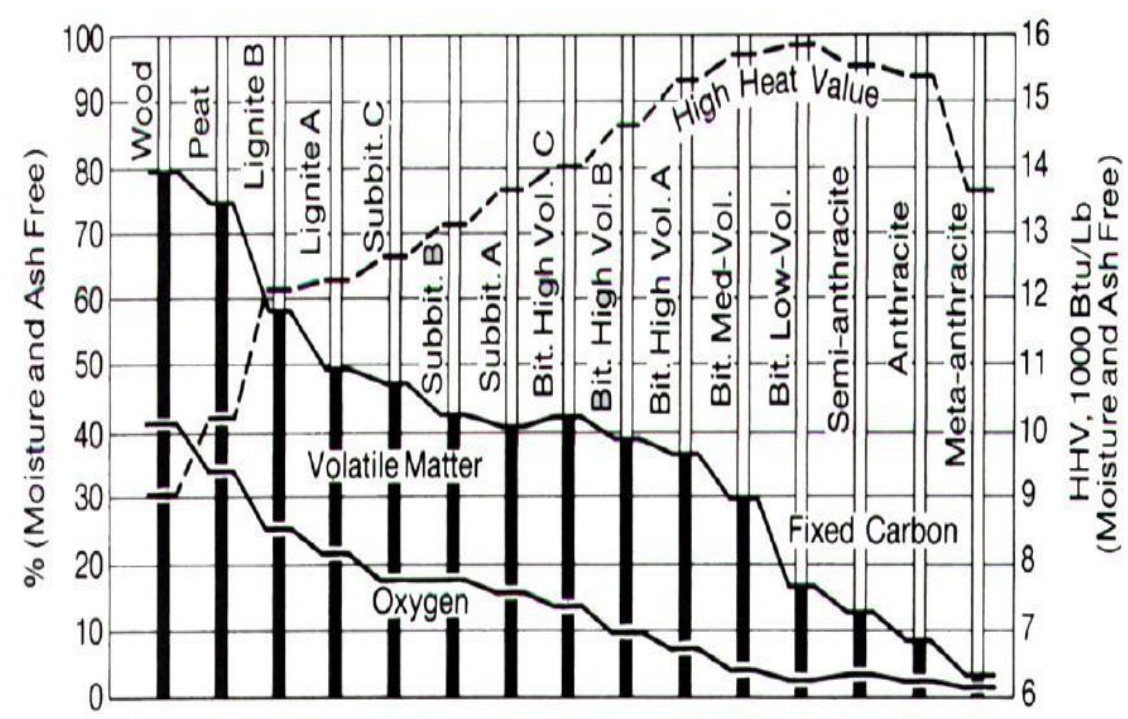

Figure 17. Volatile matter depending on coal rank

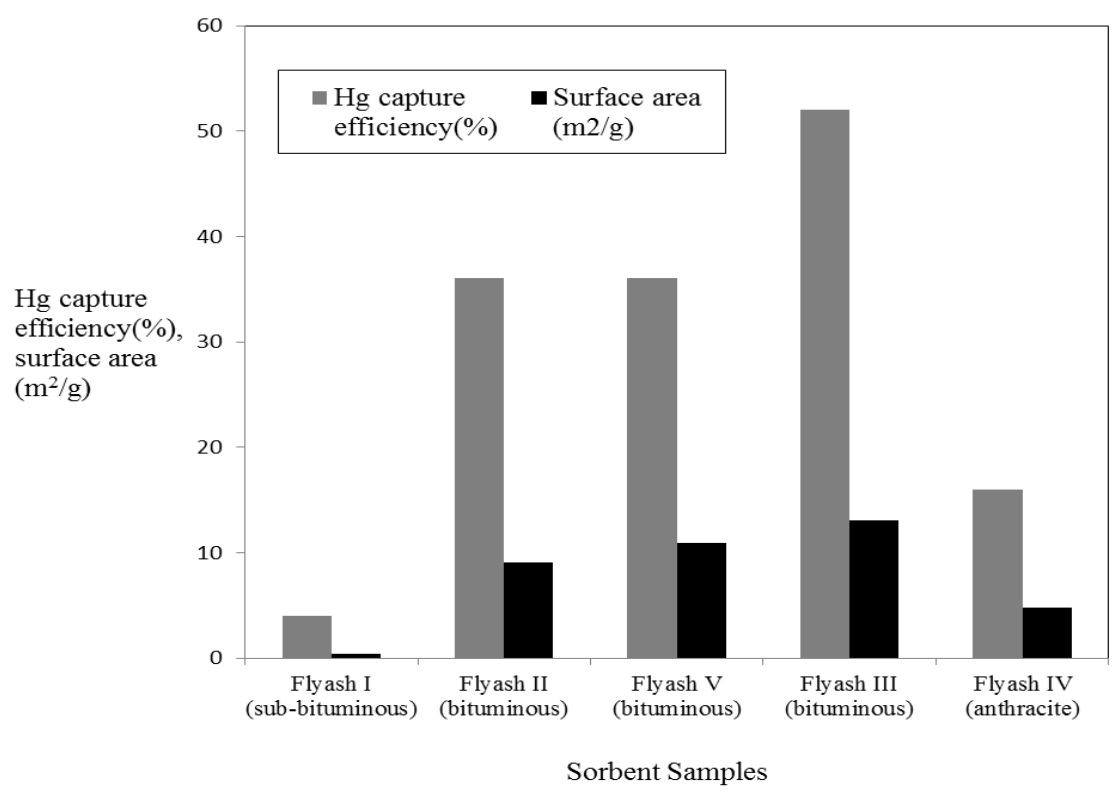

Figure 18. The effect of coal rank for Hg capture efficiency

\section{Conclusions}

Five flyash samples are investigated in order to examine the relation among LOI, surface area, and mercury capture efficiency. Flyash $\mathrm{C}$ shows high mercury capture efficiency of $52 \%$ due to its residual carbon content and surface area.

The porous structure (or surface area) is highly dependent on the carbonaceous content following from the devolatilization process during the coal combustion that produces the flyash samples. Mercury uptake efficiency is proportional to unburned carbon content for low rank of coal conditions.

The physical mechanism for mercury adsorption onto activated carbon has a closer 
correlation with the surface area open to mercury vapor even though carbon content in ash is a good index for mercury capture. Accordingly, ash from anthracite, which has a comparatively low level of volatile matter, shows low mercury capture efficiency despite its high carbonaceous content.

\section{Acknowledgement}

This research, IUCRP Project gcp06-10236, has been supported by General Electric Corporation and the University of California Discovery program.

\section{References}

Bartok, W., \& Sarofim, A. F., (1991). Fossil fuel combustion: A source book. Wiley, NY: Wiley-Interscience.

Conti, J. J. (2010). International energy outlook 2010. U.S. Energy information administration. Available: http://www.eia.gov/forecasts/archive/ieo10/pdf/0484(2010).pdf

Romero, C. E., Li, Y., Bilirgen, H., Sarunac, N., \& Levy, E. K. (2005). Modification of boiler operating conditions for mercury emissions reductions in coal-fired utility boilers. Fuel 85 (2006), 204-212.

Scala, F. \& Clack, H. L. (2008). Mercury emissions from coal combustion: Modeling and comparison of $\mathrm{Hg}$ capture in a fabric filter versus and electrostatic precipitator. Hazardous Materials, 152(2), 616-623. http://dx.doi.org/10.1016/j.jhazmat.2007.07.024

Serre, S. D., Gullett, B. K., \& Ghorishi, S. B., (2000). Elemental mercury capture by activated carbon in a flow reactor. Presented at AWMA conference, Salt Lake City, UT.

Shannon D. Serre and Geoffrey D. Silcox (2000). Adsorption of Elemental Mercury on the Residual Carbon in Coal Fly Ash, Ind. Eng. Chem. Res., Vol. 39, 1723-1730, No. 6

\section{Glossary}

CEMS Continuous Emission Monitoring System

EIAEnergy Information Administration

FBC Fluidized Bed Combustion

LOI Loss-on-ignition

PCC Pulverized Coal Combustion

SEM Scanning Electron Microscopy

PRB Powder River Basin 


\section{Macrothink \\ Environmental Management and Sustainable Development \\ ISSN 2164-7682 \\ 2015, Vol. 4, No. 2}

\section{Copyright Disclaimer}

Copyright for this article is retained by the author(s), with first publication rights granted to the journal.

This is an open-access article distributed under the terms and conditions of the Creative Commons Attribution license (http://creativecommons.org/licenses/by/3.0/). 